\author{
A.R. Yeshkeyev \\ Ye.A.Buketov Karaganda State University, Kazakhstan \\ (E-mail: modth1705@mail.ru)
}

\title{
About central types and the cosemanticness of the $\Delta$-PM fragment of the Jonsson set
}

\begin{abstract}
This article is concerned with the enrichment of the signature. In own time, when studying the stability of the theory and the concept of an elementary pair of models, Mustafin T.G. had noticed that these things are related to each other and he introduced the concept $T^{*}$-stability [1]. In fact, some enrichment of the signature is considered. Generally speaking, the theories obtained in the extended language are incomplete, therefore, the number of such completions of these theories is sought. This number also determines stability in the sense of $T^{*}$-stability. It was noted by E.A.Palyutin in [2] that the concept of $T^{*}$-stability is not invariant with respect to definability of type. But we know that in the classical sense of S.Sellach the stability of the theory is invariant with respect to the definability of type. Therefore Palyutin E.A. had introduced the concept $E^{*}$-stability, which preserved the definability of type. Author of this article [3] considered this formulation of the problem for the Jonsson theories. We call it in the class of Jonsson theories or in positive Jonsson theories $(\Delta-P J, \Delta-P M, \Delta-P R)$ enrichment of the signature is admissible if the stability was obtained in the considering case is invariant with respect to the definability of type. In this article, all considering enrichments are admissible. Let the enrichment be $\Gamma=\{P\} \cup\{c\}$, where $P$ is unary predicate symbol with new constant symbol. In connection with admissible enrichments one of the authors of this paper introduced the notion of the central type. Many theorems which obtained before the enrichment of the signature are translated in the language of central types. In this article we will consider similarly questions for central types of positive generalizations of Jonsson fragments.
\end{abstract}

Keywords: Jonsson theory, Jonsson set, fragment of Jonsson set, central type, cosemanticness, stability.

When studying the properties of forking for $\Delta-P M$-theory considered an axiomatic approach. A similar one was considered in $[4,5]$, respectively, for the Jonsson theory and $\Delta$-PM-theory. The main result is the following theorem.

Theorem 1. Let $T$ be a $\Delta$-PM-Jonsson fragment, $\alpha$-Jonsson, perfect, complete for $\Sigma_{\alpha+1}$ sentences. Then following conditions are equivalent:

1) the relation $P J N F$ satisfies axioms 1-7 [6] with respect to the theory $T$;

2) $T^{*}$ is stable and for any $p \in P, A \in A((p, A) \in P J N F \Leftrightarrow p$ does not forking over $A$ in the sense of Shelah).

The idea of a central type appears when we consider an enriched signature.

$\Delta-P M$-theories were determined in [7]. Such theories are a positive generalization of the generalized-Jonsson theories introduced in [8].

Let $T$ be an arbitrary $\Delta$-PM-Jonsson fragment in the language of the signature $\sigma$. Let $C$ be a semantic model of the theory T. $A \subseteq C$. Let $\sigma_{\Gamma}(A)=\sigma \cup\left\{c_{a} \mid a \in A\right\} \cup \Gamma$, where $\Gamma=\{P\} \cup\{c\}$. Consider the following theory $T_{\Gamma}^{P M}(A)=T h_{\Pi_{\alpha \in A}^{+}}(C, a)_{a \in A} \cup\{P(c)\} \cup\left\{{ }^{\prime \prime} P \subseteq^{\prime \prime}\right\}$, where $\left\{{ }^{\prime \prime} P \subseteq^{\prime \prime}\right\}$ is an infinite set of sentences, which means that the interpretation of the symbol $P$ is a positively existentially closed submodel in the signature $\sigma$. We denote by $S_{\Gamma}^{P M}$ the set of all $\Sigma_{\alpha+1}^{+}$-completions of Jonsson fragment. $T$ is $J$-P- $\lambda$-stable if $\left|S_{\Gamma}^{P M} \leq \lambda\right|$ for any $A$ such that $|A| \leq \lambda$.

Consider all the completions of the center $T^{*}$ of Jonsson fragment $T$ in the new signature $\sigma_{\Gamma}$, where $\Gamma=\{c\}$. Due to the fact that Jonsson fragment $T^{*}$ is $\Delta-P M$ there is its center and we will denote it as $T^{c}$. With the restriction of $T^{c}$ to the signature $\sigma$ Jonsson fragment $T^{c}$ becomes a complete type. We will call this type the central type of Jonsson fragment $T$.

In the frame of the above defined definitions the following theorem is obtained.

Theorem 2. Let $T$ be $\Sigma_{\alpha+1}$-complete, perfect, $\Delta$-PM-Jonsson fragment. Then the following conditions are equivalent:

1) Jonsson fragment $T^{C}$ is $P$ - $\lambda$-stable in the sense of [9];

2) Jonsson fragment $T^{*}$ is $J$ - $P$ - $\lambda$-stable. 
Let we define axiomatically the concept of forking for the $\Delta$-PM-Jonsson fragment, when it is a perfect $\alpha$-Jonsson fragment. We generalized the results of $[4,5]$.

We introduce the following definitions.

Definition 1. Let $M$ be $\Sigma_{\alpha+1}^{+}$-saturated $\Delta$-positively $\alpha+1$-existentially closed model of cardinality $\kappa(\kappa$ is a sufficiently large cardinal) of $\Delta$-PM-theory $T\left(\Sigma_{\alpha+1}^{+}\right.$-saturation means saturation with respect to $\Sigma_{\alpha+1}^{+}$-types in its power).

Let $T$ be a Jonsson fragment, $S^{P M}(X)$ is the set of all positive $\Sigma_{\alpha+1}^{+}$-complete $n$-types over $X$ which joint with $T$ for every finite $n$.

Let $A$ be a class of all subsets $M, P$ is class of all $\Sigma_{\alpha+1}^{+}$-types (not necessarily complete), let $P J N F \subseteq P \times A$ be some binary relation. We impose on the $P J N F$ (positively Jonsson non-forking) following axioms:

Axiom 1. If $(p, A) \in P J N F, f \in A u t(M), f(A)=B$, then $(f(p), B) \in P J N F$.

Axiom 2. If $(p, A) \in P J N F, q \subseteq p$, then $(q, A) \in P J N F$.

Axiom 3. If $A \subseteq B \subseteq C, p \in S^{P M}(C)$, then $(p, A) \in P J N F \Leftrightarrow(p, B) \in P J N F$ and $(p\lceil B, A) \in P J N F$.

Axiom 4. If $A \subseteq B, \operatorname{dom}(p) \subseteq B,(p, A) \in P J N F$, then $\exists q \in S^{P M}(B),(p \subseteq q$ and $(q, A) \in P J N F)$.

Axiom 5. There is a cardinal $\mu$ such that if $A \subseteq B \subseteq C, p \in S^{P M}(B),(p, A) \in P J N F$ then $\mid\left\{q \in S^{P M}(C)\right.$ : $p \subseteq q$ and $(q, A) \in P J N F\} \mid<\mu$.

Axiom 6. There is a cardinal $\rho$ such that $\forall p \in P, \forall A \in A$, if $(p, A) \in P J N F$, then $\exists A_{1} \subseteq A,\left(\left|A_{1}\right|<\rho\right)$ and $\left(p, A_{1}\right) \in P J N F$.

Axiom 7. If $p \in S^{P M}(A)$, then $(p, A) \in P J N F$.

The next arrangement is important. In fact, we will talk about the semantic aspect of $\Delta$ - $P M$-Jonsson fragment. If $\Delta$-PM-Jonsson fragment $T$ is $\alpha$-Jonsson then with $\operatorname{Mod} T$ we work as with the class of models of some Jonsson theory. If $\Delta$-PM-Jonsson fragment $T$ is not $\alpha$-Jonsson then as with $\operatorname{Mod} T$ we will consider the class of its positively existentially closed models $\Sigma_{\alpha+1}^{+} T$. Such approach for class $\Sigma_{\alpha+1}^{+} T$ of existentially closed models of an arbitrary universal Jonsson fragment $T$ was considered in [10]. Since two cases are possible with respect to Jonsson fragments: perfect and imperfect, we will adhere to the following. It is well known from [6] that if Jonsson theory is perfect then the class of its existentially closed models is elementary and coincides with $\operatorname{Mod} T^{*}$, where $T^{*}$ its center. Otherwise, i.e. if theory $T$ is imperfect, we proceed similarly [10], only instead of $\operatorname{Mod} T$ we work with the class $\Sigma_{\alpha+1}^{+} T$ that considered as an extension of the class $E_{T}$ of existentially closed models (both classes always exist), and depending on the perfectness and imperfectness of Jonsson fragment $T$ model-theoretic properties of the class $\Sigma_{\alpha+1}^{+} T$ is of special interest. In this article, for the considered $\Delta$ considering $\Delta$-PM-Jonsson fragments are $\Delta-P M$-perfect, which is a natural generalization of perfectness in the Jonsson sense.

Definition 2. We say that $\Delta$-PM-Jonsson fragment $T$ is $P M$ - $\lambda$-stable if for any model $A \in \Sigma_{\alpha+1}^{+} T$, for any subset $X$ of the set $A,|X| \leq \lambda \Rightarrow\left|S^{P M}(X)\right| \leq \lambda$. $\Delta$-PM-Jonsson fragment $T$ is $P M$-stable if it is $P M$ - $\lambda$-stable for some $\lambda$.

Theorem 3. Let $T$ be $\Delta$-PM-Jonsson fragment, $\alpha$-Jonsson, perfect, complete for $\Sigma_{\alpha+1}$ sentences. Then the following conditions are equivalent:

1) the relation $P J N F$ satisfies axioms 1-7 with respect to Jonsson fragment;

2) $T$ is stable and for any $p \in P, A \in A((p, A) \in P J N F \Leftrightarrow p$ does not forking over $A$ in the sense of Shelah).

Proof. $1 \Rightarrow 2$. Let $\lambda=2^{\rho|T| \mu}$, where $\lambda, \rho, \mu$ are cardinals, corresponding to axioms 1-7. Now we show that $T$ is $P M$ - $\lambda$-stable. Then, by theorem 2.1 from [11] we will have that $T^{*}$ is $\lambda$-stable. It's obvious that $\lambda^{p}=\lambda$. Let $|A|=\lambda$. If $p \in S^{P M}(A)$, then by axiom $7(p, A) \in P J N F$ and by axiom 6 there exists $A_{p} \subseteq A$ such that $\left|A_{p}\right|<p$ and $\left(p, A_{p}\right) \in P J N F$. Then by axiom $3\left(p\left\lceil A_{p}, A\right) \in P J N F\right.$. We denote by $p\left\lceil A_{p}\right.$ through $g(p)$. By axiom $5\left|\left\{q \in S^{P M}(A): g(q)=g(p)\right\}\right|<\mu$. Consequently, $\left|S^{P M}(A)\right| \leq\left|\left\{g(p): p \in S^{P M}(A)\right\}\right| \cdot \mu \leq\left|A^{p}\right| \cdot 2^{p|T|} \cdot \mu$ $\leq \lambda^{p} \cdot \lambda \cdot \lambda=\lambda^{p}=\lambda$.

Consequently, $T$ is $P M$ - $\lambda$-stable. And we conclude that $T^{*}$ is $\lambda$-stable by theorem 2 from [11].

Now let $(p, A) \in P J N F$. We show that $p$ is not forking over $A$. Let $B=\operatorname{dom}(p)$. Then by axiom 4 there exists $q \in S^{P M}(B)$ such that $p \subseteq q$ and $(q, A) \in P J N F$. Let we prove that $q$ is not forking over $A$ (then $p$ is not forking over $A$ by axiom 2). Suppose the converse. Then in view of the perfect theory $T$ and definitions 1,2 there is a finite set of positive existential formulas $\Sigma_{0}^{+}$such that $q \vdash \cup\left\{\varphi: \varphi \in \Sigma_{0}^{+}\right\}$and every formula $\varphi \in \Sigma_{0}^{+}$ divided over $A$. Let $C=B \cup D, D$ be the set of constants entering at least in one of the formulas of $\Sigma_{0}^{+}$. By axiom 4 there exists $q_{0} \in S^{P M}(C)$ such that $q \in q_{0}$ and $\left(q_{0}, A\right) \in P J N F$. It's obvious that $q_{0} \vdash \cup\left\{\varphi: \varphi \in \Sigma_{0}^{+}\right\}$ there is $\varphi(\bar{x}, \bar{a}) \in q_{0} \cap \Sigma_{0}^{+}$. Using theorem 1, the compactness theorem and divisibility $\varphi(\bar{x}, \bar{a})$ over $A$, we can 
show the existence of a sequence $\overline{a_{\alpha}}: \alpha<\mu^{+}$and elementary monomorphisms $f_{\alpha}, \alpha<\mu^{+}$identical to $A$ so that $\left\langle\bar{a}_{\alpha}: \alpha<\mu^{+}\right\rangle$and $f_{\alpha}, \alpha<\mu^{+}$is $k$-disjoint for some $k<\omega$.

Let $E=C \cup\left\{\overline{a_{\alpha}}: \alpha<\mu^{+}\right\}, q_{\alpha}=f_{\alpha}\left(q_{0}\right), 0<\alpha<\mu^{+}$. By axiom $1\left(q_{0}, A\right) \in P J N F, \alpha<\mu^{+}$, by axiom 4 there exist $q_{\alpha}^{\prime} \in S^{P M}(E)$ such that $q_{\alpha} \subseteq q_{\alpha}^{\prime}$ and $\left(q_{\alpha}^{\prime}, A\right) \in P J N F$. It's clear that $\varphi\left(\bar{x}, \bar{a}_{\alpha}\right) \in q_{\alpha}^{\prime}, \alpha<\mu^{+}$. We have $\left|\left\{q_{\alpha}^{\prime}: \alpha<\mu^{+}\right\}\right|=\mu^{+}$such that $\varphi\left(\bar{x}, \overline{a_{\alpha}}\right): \alpha<\mu^{+}$is $k$-disjoint. We obtained the contradiction with axiom 5. Consequently, $q$ is not forking over $A$. Thus, we have that if $(p, A) \in P J N F$ then $p$ is not forking over $A$. Prove in the opposite direction. Let $P$ is not forking over $A$. Since Jonsson fragment $T$ is perfect then $T^{*}$ is model complete [11] and for us it is sufficient to work only with existential types and consider $\Sigma_{\alpha+1^{-}}^{+}$ saturated positive $\alpha+1$-existentially closed models of the theory $T$. We need to prove that $(p, A) \in P J N F$. Let $M \supseteq A, M \supseteq \operatorname{dom}(p),|M|>2^{\rho|T| \cdot \mu}$ and $M$ is $\Sigma_{\alpha+1}^{+}$-saturated model of the theory $T^{*}, t \in S^{P M}(M), p \subseteq t, t$ is not forking over $A$. By axiom $7\left(t\lceil A, A) \in P J N F\right.$ and by axiom 5 there exists $q \in S^{P J}(M)$ such that $q \supseteq t\lceil A$ and $(q, A) \in P J N F$. As shown above $(q, A) \in P J N F$ implies that $q$ is not forking over $A$. By Lemma 1 there exist automorphisms $f$ of the model $M$ identical to $A$ such that $y=f(q)$. Then by axiom $1(t, A) \in P J N F$ and by axiom $2(p, A) \in P J N F$. Consequently, $1 \Rightarrow 2$ is proved.

$2 \Rightarrow 1$. Since the center of Jonsson fragment $T$ namely $T^{*}$ is complete, then to it can be applied the properties of forking in the sense of Shelah. The obtained results (analogues of axioms 1-7 for complete theories) can be easily restricted to generalizations of the corresponding concepts in $\alpha$-Jonsson sense.

At the moment we are ready to give a proof of the fact that the stability properties of central types as stability in the usual sense for centers with a distinguished predicate coincide with stability with a distinguished predicate in the $P M$-sense.

We introduce the following notation.

Let $T$ be an arbitrary $\triangle$-PM-Jonsson fragment in the language of the signature $\sigma$. Let $C$ be semantical model of Jonsson fragment $T$. $A \subseteq C$. Let $\sigma_{\Gamma}(A)=\sigma \cup\left\{c_{a} \mid a \in A\right\} \cup \Gamma$, where $\Gamma=\{P\} \cup\{c\}$. Consider following Jonsson fragment $T_{\Gamma}^{P M}(\bar{A})=T h_{\Pi_{\alpha+2}^{+}}(C, a)_{a \in A} \cup\{P(c)\} \cup\left\{{ }^{\prime \prime} P \subseteq^{\prime \prime}\right\}$, where $\left\{{ }^{\prime \prime} P \subseteq^{\prime \prime}\right\}$ is an infinite set of sentences that says that the interpretation of the symbol $P$ is a positively existentially closed submodel in the signature $\sigma$. This Jonsson fragment is not necessarily complete. Therefore it can have finite models.

Through $S_{\Gamma}^{P M}$ we denote the set of all $\Sigma_{\alpha+1}^{+}$-completions of Jonsson fragment $T$ is $J$ - $P$ - $\lambda$-stable if $S_{\Gamma}^{P M} \leq \lambda$ for any $A$ such that $|A| \leq \lambda$. We consider all the completions of the center $T^{*}$ of the Jonsson fragment $T$ in the new signature $\sigma_{\Gamma}$, where $\Gamma=\{c\}$. By virtue of the fact that Jonsson fragment $T$ by condition $\Delta$-PM-Jonsson fragment then nothing will change in the enriched language. Further, due to the fact that the condition $T$ is perfect as $\alpha$-Jonsson fragment then $T^{*}$ is $\Delta$-PM-Jonsson fragment. Then there is its center and it is one of the completions of the Jonsson fragment $T^{*}$ in an enriched language. This center we denote as $T^{c}$. With restriction $T^{c}$ to the signature $\sigma$ Jonsson fragment $T^{c}$ becomes a complete type. We call this type the central type of the Jonsson fragment $T$.

In the frame of above definitions the following theorem is obtained.

Theorem 4. Let $T$ be $\Sigma_{\alpha+1}$-complete, perfect, $\Delta$-PM-Jonsson fragment. Then following conditions are equivalent:

1) the Jonsson fragment $T^{c}$ is $P-\lambda$ stable in the sense [9];

2) the Jonsson fragment $T^{c}$ is $P M-\lambda$-stable.

Proof. From 1) to 2) the proof is trivial, since if the completions are not more than $\lambda$ then $\Sigma_{\alpha+1}^{+}$-completions also not more than $\lambda$. We prove this from 2) to 1). Suppose that Jonsson fragment $T^{c}$ is $P M$ - $\lambda$-stable. This is equivalent to the fact that $T_{\Gamma}^{P M}(A)$ in the signature $\sigma_{p}(A)=\sigma_{A} \cup\{P\}$ equals the corresponding Kaiser shell $T^{0}$. Because of the completeness of Jonsson fragment $T$ we have that $T^{0}=T^{*}$ and $\Sigma_{\alpha+1}^{+} T=M o d T^{*}$ (By virtue of perfectness) and $T_{\Gamma}^{P M}(A)=T^{0}$ will be a perfect Jonsson fragment. Suppose that the Jonsson fragment $T^{0}$ have not more than $\lambda \Sigma_{\alpha+1}^{+}$-completions. The center of Jonsson fragment $T$ in the new signature $\sigma_{p}(A)=\sigma_{A} \cup\{P\}$ will be equal to $\operatorname{Th}(C, a)_{a \in A} \cup\left\{P\left(c_{a}\right) \mid a \in A\right\}\left\{{ }^{\prime \prime} P \leq^{\prime \prime}\right\}$. We need to show that $T^{*}$ have completions no more than $\lambda$. By that $T^{*}$ will be $P$ - $\lambda$-stable (in the sense [9]). Let as clear why $T^{*}$ is not complete in the new signature. The addition of constants give only non-essential extensions which does not change the number of types of existentially closed submodels of $C$. An essential role is played by realizations of the predicate $P$. In this case, realization of the predicate $P$ will be some elementary submodel $M$ of the model $C$. Since the semantic model $C$ of $\alpha$-Jonsson fragment $T$ is existentially closed [10] then by virtue of the predicate $P$ in $C(M \leq C)$ follows that $M \in \Sigma_{\alpha+1}^{+} T$. Consider an arbitrary completion $T^{\prime}$ in the new signature. By the definition $T^{*}$ there is such a model $M$ from $\Sigma_{\alpha+1}^{+} T$ such that $T^{\prime}=T h(C, M, a)_{a \in A}$, where $M$ is interpretation of the predicate $P$ in the semantic model $C$. We have that $T^{\prime}=T h(C, M, a)_{a \in A}$ is Jonsson. In this case, by virtue of the model 
completeness of $T^{\prime}$ any formula in $T^{\prime}$ is equivalent to some existential formula in $T^{\prime}$. Then by $\Sigma_{\alpha+1}$-completeness of Jonsson fragment $T$ such completions by condition (2) are not more than $\lambda$. Thus the statement is proved.

We note that since Jonsson fragment which complete for existential sentences satisfies the joint embedding property (JEP), but the converse is not true condition of $\Sigma_{\alpha+1}$-completeness in the theorem can not be removed. Due to the fact that there is a continuum of not elementary equivalent among themselves existentially closed groups and the groups theory is Jonsson, then we can conclude that in the hypothesis of the theorem one can not be removed the requirement of perfectness.

Let $T$ be an arbitrary $\Delta-P J$-Jonsson fragment in the first-order language of the signature $\sigma$. Let $C$ is semantical model of Jonsson fragment $T . A \subseteq C$. Let $\sigma_{\Gamma}(A)=\sigma \cup\left\{c_{a} \mid a \in A\right\} \cup \Gamma, T_{\Gamma}^{P J}(A)=T h_{\forall \exists^{+}}(C, a)_{a \in A}$ $\cup\left\{P\left(c_{a}\right) \mid a \in A\right\} \cup\{P(c)\} \cup\left\{{ }^{\prime \prime} P \subseteq^{\prime \prime}\right\}$, where $\left\{{ }^{\prime \prime} P \subseteq^{\prime \prime}\right\}$ is infinitely many sentences expressing the fact that the interpretation of the symbol $P$ is an existentially closed submodel in the language of the signature $\sigma$. Consider all completions of Jonsson fragment $T^{*}$ for Jonsson fragment $T$ in the language of the signature $\sigma_{\Gamma}$, where $\Gamma=\{c\}$. Since $T^{*}$ is $\Delta$-PJ-Jonsson fragment has a center, we denote it by $T^{c}$. When the theory $T^{c}$ is restricted to a signature $\sigma$ the theory $T^{c}$ becomes a complete type. This type is called the central type of Jonsson fragment $T$. Note that all semantic models are elementarily equivalent. Because of this and the perfectness of Jonsson fragment the definition of the central type is correct. In this article there are no statements in the language of central types for $\Delta$-PJ-Jonsson fragment, but the central types will be considered for another class of Jonsson fragments associated with the class $\Delta-P J$-Jonsson fragments. In order to see how these classes are related definitions of the central type are given in both cases.

Definition 3. Let $A$ be some infinite model of the signature $\sigma . A$ is called $\Delta$-PM-model if the set of the sentences $T_{\Gamma}^{P J}(A)$ is $\Delta$-PJ-Jonsson fragment in the enriched language.

The Jonsson fragment $T_{\Gamma}^{P J}(A)$ will be denoted by $\forall \exists^{+}(A)$.

The following result generalizes proposition 1 from [12] and lemma 9 of [13].

Lemma 1. Let $T$ be $\Delta$-PJ-Jonsson fragment complete for existential sentences in enrichment $\Gamma=\{P\} \cup\{c\}$. Then any infinite model of Jonsson fragment of center of Jonsson fragment $T$ is $\Delta$ - $P J$-model.

Proof. If the fragment $T$ is Jonsson then it follows from the fact that the positive Kaiser shell $T^{0}$ for $T$ is Jonsson, where $T^{0}$ is $T h_{\forall \exists}^{+}(C), C$ is semantical model of the theory $T$ and the interpretations of the symbols $P$ and $c$ do not influence on the Jonssonness because for the corresponding morphisms under consideration for $\Delta$-JEP and $\Delta$-AP realizations of the symbols $P$ and $c$ are transformed into the corresponding images, since the role $P$ is played by the existentially closed submodel and the constant becomes a constant. In the case where the fragment $T$ is not Jonsson then as a semantic model we consider the universal domain from [14, 15]. Reasoning about maximum of the positive Kaiser shell is transferred completely to the universal domain.

Definition 4. The models $A$ and $B$ are called $\Delta$-PJ-equivalent if for any $\Delta$ - $P J$-theory $T A \models T \Leftrightarrow B \models T$ and denoted by $A \equiv_{P}^{\Delta} B$.

Lemma 2. Let $A$ and $B$ models of the signature $\sigma_{\Gamma}(A)=\sigma \cup\left\{c_{a} \mid a \in A\right\} \cup \Gamma$. Then the following conditions are equivalent:

1) $A \equiv{ }_{P J}^{\Delta} B$

2) $\forall \exists^{+}(A)=\forall \exists^{+}(B)$.

Proof. In the Jonsson case the proof follows from [12]. In the remaining cases with the help of lemma 1 it is easy to obtain positive generalizations of this proof.

Definition 5. Two $\Delta$-PJ-Jonsson fragments $T_{1}$ and $T_{2}$ are called $\Delta$-PJ-cosemantic $T_{1} \bowtie_{P J} T_{2}$, if they have a general semantic model, in the case when $T_{1}$ and $T_{2}$ are Jonsson fragments we have a general universal domain in the case when they are not Jonsson.

Definition 6 . Models $A$ and $B$ of the signature $\sigma$ are called $\Delta$-PJ-cosemantic $A \bowtie_{P J}^{\Delta} B$ if for any $\Delta-P J$ Jonsson fragment $T_{1}$ such that $A \models T_{1}$, there is $\Delta$-PJ-Jonsson fragment $T_{2}, \Delta$-PJ-cosemanticness with $T_{1}$, such that $B \models T_{2}$. And vice versa.

For any models the following implications are true:

$$
A \equiv B \Rightarrow A \equiv_{P}^{\Delta}{ }_{P} B \Rightarrow A \bowtie_{P}{ }_{P} B .
$$

The next arrangement is very important. In fact we will talk about the semantic aspect of the $\Delta-P J$ Jonsson fragment. If the $\Delta-P J$-fragment is Jonsson then with $\operatorname{ModT}$ we work as with the class of models of some Jonsson fragment. If the $\Delta-P J$-fragment is not Jonsson then as $\operatorname{Mod} T$ we will consider the class of its positively existentially closed models $E_{T}^{+}$. Such an approach for the class $E_{T}$ of existentially closed models of an arbitrary universal theory $T$ was considered in [2]. Since two cases are possible with respect to the Jonsson 
fragments: perfect and imperfect, we will adhere to the following. It is well known from [3] that if Jonsson theory $T$ is perfect then the class of its existentially closed models $E_{T}$ is elementary and coincides with $\operatorname{Mod} T^{*}$, where $T^{*}$ is its center. Otherwise, i.e. if the theory $T$ is imperfect, we proceed as in [13], i.e. instead of ModT we work with the class $E_{T}^{+}$. When an arbitrary $\Delta$-PJ-fragment $T$ is considered, then the class $E_{T}^{+}$is regarded as an extension of the class $E_{T}$ (both classes always exist) and depending on the perfectness and imperfectness of fragment $T$, the model-theoretic properties of the class $E_{T}^{+}$are of particular interest.

Lemma 3. Let $T_{1}^{\prime}$ and $T_{2}^{\prime}$ are centers of Jonsson fragments $T_{1}$ and $T_{2}$ and they are $\Delta$ - $P J$-Jonsson fragments in $\sigma_{\Gamma}(A)=\sigma \cup\left\{c_{a} \mid a \in A\right\} \cup \Gamma$. And $C_{1}$ is semantic model of $T_{1}, C_{2}$ is semantic model of $T_{2}$. If $\left(T_{1}^{*}\right)_{\forall^{+}}=\left(T_{2}^{*}\right)_{\forall^{+}}$ then $T_{1}^{*} \bowtie_{P J} T_{2}^{*}$. Proof. In the Jonsson case from the fact that positive universal consequences $T_{2}$ and $T_{1}$ coincide it follows that they are model-joint.

Accordingly, the semantic model of $T_{1}$ is a model of $T_{2}$ and the semantic model of $T_{2}$ is a model of $T_{1}$. Next we apply a positive generalization of the proof in [7] with the help of lemmas 1,2 . In the case of the not Jonsson case it suffices to note that if we consider universal domains as semantic models then it is easy to see that they are positively existential models in the sense of [14], [15]. And since by virtue of the remark about the semantic aspect of $\Delta$-PJ-fragments we are working in the not Jonsson case with models of $E_{T}^{+}$, and since all sentences become immersions we can easily repeat the proof similarly to the Jonsson case.

Theorem 5. Let $T_{1}^{*}$ and $T_{2}^{*}$ as in the conditions of lemma 3 are $\Delta$ - $P J$-fragments and $C_{1}$ is semantic model of $T_{1}, C_{2}$ is semantic model of $T_{2}$. Then the following conditions are equivalent:

1) $C_{1} \bowtie_{P J}^{\Delta} C_{2}$;

2) $C_{1} \equiv{ }_{P J}^{\Delta} C_{2}$

3) $C_{1}=C_{2}$.

Proof. Similarly by lemma 3 we consider two cases. In the Jonsson case we repeat the proof from [12] only with the difference that $\Delta$ is closed with respect to positive Boolean combinations and is fixed as above. In the not Jonsson case $C_{1}$ is replaced by $U_{1}$ and $C_{2}$ replaced by $U_{2}$, where $U_{1}$ and $U_{2}$ are universal domains, respectively, for $T_{1}$ and $T_{2}$. Then the above statement follows from that $U_{1} \in E_{T_{1}}^{+}$and $U_{2} \in E_{T_{2}}^{+}$. And it remains to apply the remark semantic aspect $\Delta-P J$-Jonsson fragments.

The following result generalizes theorem 4 of [12].

Theorem 6. Let $A$ and $B$ be the $\Delta$-PJ-models of the signature $\sigma_{\Gamma}(A)=\sigma \cup\left\{c_{a} \mid a \in A\right\} \cup \Gamma$. Then the following conditions are equivalent:

1) $A \bowtie_{P J}^{\Delta} B$;

2) $\forall \exists^{+}(A) \bowtie_{P J}^{\Delta} \forall \exists^{+}(B)$.

Proof. In the Jonsson case, as in the previous theorem, it suffices to consider a positive generalization of the proof from [12] in the sense that $\Delta$ is closed with respect to positive Boolean combinations and is fixed as above. In the not Jonsson case, by the conditions of the theorem, it follows that the set of sentences $T h_{\forall \exists+}(A)$ and $T h_{\forall \exists^{+}}(B)$ from $T_{\Gamma}^{P J}(A)=T h_{\forall \exists^{+}}(C, a)_{a \in A} \cup\left\{P\left(c_{a}\right) \mid a \in A\right\} \cup\{P(c)\} \cup\left\{{ }^{\prime \prime} P \subseteq^{\prime \prime}\right\}$ in the enriched language are $\Delta$-PJ-Jonsson fragments. Then for them it is possible to apply a remark about the semantic aspect of the $\Delta$-PJ-Jonsson fragments.

In [13] a class of theories was introduced which in the intersection with the class of Jonsson fragments generalizes it and also contains generalized Jonsson fragments introduced in [8]. It is interesting to further transfer the results obtained to these fragments and also to see the connection with the central types in the considering enrichment.

Consider all the completions of the center $T^{*}$ of Jonsson fragment $T$ in the new signature $\sigma_{\Gamma}$, where $\Gamma=\{c\}$. The following fact allows us to work with positive generalizations of Jonsson fragments in the enriched signature. We note $\left(^{*}\right.$ ) (taken from [13]) that if the fragment $T$ is $\Delta$-PJ-Jonsson then in the enriched language with respect to the conditions of the theorem the center $T^{*}$ will be the same, i.e. Jonsson fragment. This is achieved as follows: the constants will go into the constants images, realization of predicate into realization of image. The necessary images are obtained by means of the corresponding mappings, which are provided by the conditions $\Delta-J E P$ and $\Delta-A P$ from $\Delta-P M$-Jonsson of the original fragment $T$. Further, due to the fact that the condition $T$ is perfect as $\alpha$-Jonsson fragment then $T^{*}$ is $\Delta$-PM-Jonsson fragment. Then there is its center and it is one of the completions of the Jonsson fragment $T^{*}$ in the enriched language. This center we denote as $T^{c}$. With restriction $T^{c}$ to the signature $\sigma$ the Jonsson fragment $T^{c}$ becomes a complete type. We call this type the central type of the theory $T$.

Let us formulate the results on the cosemantic for the positive Mustafian fragments in the enriched signature.

Let $m \leq w ; \sigma_{\Gamma}(A)=\sigma \cup\left\{c_{a} \mid a \in A\right\} \cup \Gamma$. 
Theorem 7 . Let $T_{1}^{*}$ and $T_{2}^{*}$ be $\Delta$-PM-Jonsson fragments, $C_{1}$ be semantic model of $T_{1}, C_{2}$ be semantic model of $T_{2}$. Then the following conditions are equivalent:

1) $C_{1} \bowtie_{P}^{\Delta} C_{2}$

2) $C_{1} \equiv \stackrel{\Delta}{P}{ }_{M} C_{2}$

3) $C_{1}=C_{2}$.

Routine proof by induction on quantifiers with an induction length of even $k$, where $k$ is the number of quantifier changes. Even, because blocks $\forall \exists$ of length 2 are considered.

Theorem 8. Let $A$ and $B$ be $\Delta-P M$-models of $T^{c}$ is the Jonsson fragment. Then the following conditions are equivalent:

1) $A \bowtie_{P}^{\Delta} B$

2) $\forall \exists_{m}^{+}(A) \bowtie_{P}^{\Delta} \forall \exists_{m}^{+}(B)$.

Proof. It follows from the above theorems 2 and 4 .

All undefined definitions, concepts and results can be found in [6, 16, 17].

\section{References}

1 Мустафин Т.Г. Новые понятия стабильности теорий // Труды советско-французского коллоквиума по теории моделей. - Караганда, 1990. - С. 112-125.

2 Палютин Е.А. E*-стабильные теории / Е.А. Палютин // Алгебра и логика. - 2003. — № 2. - С. $194-210$.

3 Ешкеев А.Р. Йонсоновские теории: учеб. пособие / А.Р. Ешкеев. - Караганда: Изд-во КарГУ, 2009. $-250 \mathrm{c}$.

4 Ешкеев А.Р. О J-форкинге совершенных йонсоновских теорий / А.Р. Ешкеев // Вестн. Караганд. ун-та. Серия Математика. - 2006. - № 3(43).

5 Ешкеев А.Р. О РЈ-форкинге в классе $\Delta$-PJ-теорий / А.Р. Ешкеев // Вестн. Казахского национ. ун-та. Серия математика, механика, информатика. - Алматы: КазНУ, 2007. - № 3(54). - С. 10-16.

6 Ешкеев А.Р. Йонсоновские теории и их классы моделей: учеб. пособие / А.Р. Ешкеев, М.Т. Касыметова. - Караганда: Изд-во КарГУ, 2016. - 346 с.

7 Ешкеев А.Р. Счетная категоричность $\Delta$-PM-теорий / А.Р. Ешкеев // 12-я Межвуз. конф. по математике, механике и информатике. - Алматы, 2008.

8 Мустафин Т.Г. Обобщенные условия Йонсона и описание обобщенно-йонсоновских теорий булевых алгебр / Т.Г. Мустафин // Математические труды. - Новосибирск: Изд-во Института математики, 1998. - Т. 1, № 2. - С. 135-197.

9 Мустафин Т.Г. О Р-стабильности полных теорий / Т.Г. Мустафин, Т.А. Нурмагамбетов // Структурные свойства алгебраических систем: сб. науч. трудов. - Караганда: Изд. КарГУ, 1990. - С. 88-100.

10 Pillay A. Forking in the category of existentially closed structures. - Connection between Model Theory and Algebraic and Analytic Geometry / A.Pillay. (A. Macintyre, ed.), Quaderni di Matematica, Vol.6, University of Naples, 2000.

11 Ешкеев А.Р. Стабильность $\Delta$-PM-теории и её центра / А.Р. Ешкеев, Г.С. Бегетаева // Вестн. Караганд. ун-та. Серия математика. - 2009. - № 4(56). - С. 29-34.

12 Mustafin E. Jonsson equivalent and cosemantical models / E. Mustafin, E. Nurkhaidarov // Quatrieme Colloque Franco-Touranien de Theorie des Modeles. Resumes des Conferences. - Marseille, 1997. P. $13-15$.

13 Ешкеев А.Р. Классификация $\Delta$-PJ-теорий по $\Delta$-PJ-косемантичности и связь с их атомными и простыми моделями / А.Р. Ешкеев. - Алматы: Бюлл. КазНУ, 2008. - № 4(59). - С. 10-17.

14 Itay Ben-Yaacov. Positive model theory and compact abstract theories / Itay Ben-Yaacov // Journal of Mathematical Logic. - 2003. - Vol. 3, No. 1. - P. 85-118.

15 Itay Ben-Yaacov. Compactness and independence in non first order frameworks / Itay Ben-Yaacov // Bulletin of Symbolic logic. - 2005. - Vol. 11, No. 1. - P. 28-50.

16 Yeshkeyev A.R. On Jonsson sets and some their properties / A.R. Yeshkeyev // Bulletin of Symbolic Logic. - 2015. - Vol. 21, No. 1. - P. 99, 100.

17 Yeshkeyev A.R. Properties of central type for fragments of Jonsson sets / A.R. Yeshkeyev // Bulletin of Symbolic Logic. - 2016. - Vol. 22, No. 3. - P. 429, 430. 


\title{
A.P. Ешкеев
}

\section{Йонсондық жиынының $\Delta$-РМ фрагментінің центральдік типтері мен косемантикалығы жайында}

\begin{abstract}
Мақалада сигнатураның байытылуы қарастырылған. Кезінде тұрақтылық туралы теориялар мен модельдердің элементарлық жұптары ұғымдарын Т.Ғ. Мұстафин қарастырған, осы ұғымдар өзара байланысты екені байқалып, ол $T^{*}$-стабильділік ұғымын енгізді. Сонымен қатар сигнатураның кейбір байытылуы зерттелді. Жалпы айтқанда, байытылған тілдегі алынған теориялар толық емес, сондықтан осы теорияларды толықтыратын сандар ізделінді. Осы сан $T^{*}$-стабильділік мағынасында стабильділік ұгымын анықтады. Е.А. Палютин $T^{*}$-стабильділік ұғымы анықталған типке қатысты инвариантты емес деп қарастырды. Бірақ біз С.Шеллахтың классикалық мағынасында стабильділік теориясы анықталған типке қатысты инвариантты болатынын білеміз. Сондықтан Е.А. Палютин типтің анықтамасын сақтайтын $E^{*}$-стабильділік ұғымын енгізді. Осы мақаланың авторы өзінің жұмыстарында осы есепті йонсондық теориялар үшін қарастырып зерттеген. Атап айтқанда, йонсондық теориялар немесе позитивті йонсондық теориялар $(\Delta-P J, \Delta-P M, \Delta-P R)$ сигнатураның байытылуы рұксат етілген, егер алынған стабильділік қарастырылған жағдайда типтің анықталуына қатысты инварианты болса. Мақалада барлық қарастырылып отырған байытулар рұксат етіледі. Айтарлық байыту келесі $\Gamma=\{P\} \cup\{c\}$ түрде болсын, мұнда $P$ - бірорынды предикат символы, жаңа константа символы. Осы байытылумен байланысты мақала авторымен центральдік тип ұғымы енгізілді. Центральдік типтердің тілінде сигнатураның байытылуына дейінгі алынған көптеген теоремалар алынды. Сонымен қатар центральдік типтер үшін йонсондық фрагменттердің позитивті байытылуының аналогиялық сұрақтары жан-жақты қарастырылған.
\end{abstract}

Kiлm сөздер: йонсондық теория, йонсондық жиын, йонсондық жиынның фрагменті, центрльдік тип, косемантикалық, тұрақтылық.

\section{A.P. Ешкеев}

\section{О центральных типах и косемантичности $\Delta$-PM фрагмента йонсоновского множества}

Статья связана с обогащением сигнатуры. В своё время при изучении стабильности теории и понятия элементарной пары моделей Т.Г.Мустафиным было замечено, что эти вещи между собой связаны, и он ввел понятие $T^{*}$-стабильности. На самом деле при этом рассматривалось некоторое обогащение сигнатуры. Вообще говоря, полученные теории в расширенном языке неполны, поэтому стараются найти число таких пополнений этих теорий. Вот это число и определяло стабильность в смысле $T^{*}$-стабильности. Е.А.Палютиным было замечено, что понятие $T^{*}$-стабильности не инвариантно относительно определимости типа. Но мы знаем, что в классическом смысле С.Шеллаха стабильность теории инвариантна относительно определимости типа. Поэтому Е.А.Палютиным было введено понятие $E^{*}$-стабильности, которое сохраняло определимость типа. Автором данной статьи в работах неоднократно была рассмотрена данная постановка задачи для йонсоновских теорий. Назовём в классе йонсоновских теорий или в позитивных йонсоновских теориях $(\Delta-P J, \Delta-P M, \Delta$ - $P R)$ обогащение сигнатуры допустимым, если получаемая стабильность в рассматриваемом случае будет инвариантна относительно определимости типа. В статье все рассматриваемые обогащения являются допустимыми. Пусть обогащение будет следующим $\Gamma=\{P\} \cup\{c\}$, где $P$ - символ одноместного предиката, символ новой константы. В связи с допустимыми обогащениями ранее автором было введено понятие центрального типа. На языке центральных типов транслируются многие теоремы, полученные до обогащения сигнатуры. Кроме того, рассмотрены аналогичные вопросы для центральных типов позитивных обобщений йонсоновских фрагментов.

Ключевые слова: йонсоновская теория, йонсоновское множество, фрагмент йонсоновского множества, центральный тип, косемантичность, стабильность. 


\section{References}

1 Mustafin, T.G. (1990). Novye poniatia stabilnosti teorii [New concepts of stability theory]. Trudy sovetskofrantsuzkoho kollokviuma po teorii modelei - In the collection The work of the French-Soviet Symposium of the Model Theory. (pp. 112-125). Karaganda [in Russian].

2 Palyutin, E.A. (2003). E*-stabilnie teorii [E*-stability theory]. Algebra i Logika - Algebra and Logic, 2, 194-210 [in Russian].

3 Yeshkeyev, A.R. (2009). Yonsonovskie teorii [Jonsson theory]. Karaganda: Izdatelstvo KarHU [in Russian].

4 Yeshkeyev, A.R. (2006). O J-forkinhe sovershennykh jonsonovskikh teorii [About $J$-forking of perfect Jonsson theories]. Vestnik Karahandinskoho universiteta. Seriia Matematika - Bulletin of Karaganda University, Series Mathematics, 3(43) [in Russian].

5 Yeshkeyev, A.R. (2007). O $P J$-forkinhe v klasse $\Delta$ - $P J$-teorii [About $P J$-forking in the class $\Delta$ - $P J$-theory] Vestnik Kazakhskoho natsionalnoho universiteta. Seriia matematika, mekhanika, informatika - Bulletin of Kazakh National University. Series Mathematics, Mechanics and Computer Science, 3(54), 10-16. Almaty: Kazakh National University [in Russian].

6 Yeshkeyev, A.R. \& Kassymetova, M.T. (2016). Yonsonovskie teorii i ikh klassy modelei [Jonsson theory and its classes of models]. - Karaganda: Izdatelstvo KarHU [in Russian].

7 Yeshkeyev, A.R. (2014). Schetnaia katehorichnost $\Delta-P M$-teorii [Countable categoricity of $\Delta-P M$ theories]. 12 Mezhvuzovskaia konferentsiia po matematike, mekhanike i informatike (10-14 sentiabria 2008 hoda) - 12th Interuniversity Conference on Mathematics, Mechanics and Computer Science. Almaty [in Russian].

8 Mustafin, T.G. (1998). Obobshchennye usloviia Yonsona i opisanie obobshchenno-yonsonovskikh teorii bulevikh alhebr [Generalized Jonsson conditions and description generalized Jonsson theories of Boolean algebras]. Matematicheskie trudy - Mathematical works, Vol. 1, 2, 135-197. Novosibirsk: Publ. of Institute Mathematics [in Russian].

9 Mustafin, T.G. \& Nurmagambetov, T.A. (1990). O P-stabilnosti polnykh teorii [About P-stability of complete theories]. Structurnye svoistva alhebraicheskikh sistem. Sbornik nauchnikh trudov - Structural properties of algebraic system. Collection of scientific papers, 88-100. Karaganda: Izdatelstvo KarHU [in Russian].

10 Pillay, A. (2000). Forking in the category of existentially closed structures. - Connection between Model Theory and Algebraic and Analytic Geometry (ed. A. Macintyre), Quaderni di Matematica, Vol. 6, University of Naples.

11 Yeshkeyev, A.R. \& Begetayeva, G.S. (2009). Stabilnost $\Delta$ - $P M$-teorii i ee tsentra [Stability of $\Delta$ - $P M$ theory and its center]. Vestnik Karahandinskoho universiteta. Seriia Matematika - Bulletin of Karaganda University. Series Mathematics, 4(56), 29-34 [in Russian].

12 Mustafin, E. \& Nurkhaidarov, E. (1997). Jonsson equivalent and cosemantical models. Quatrieme Colloque Franco-Touranien de Theorie des Modeles. Resumes des Conferences, 13-15. Marseille.

13 Yeshkeyev, A.R. (2008). Klassifikatsiia $\Delta$-PJ-teorii po $\Delta$-PJ-kosemantichnosti i sviaz s ikh atomnymi i prostymi mideliami [Clasification of $\Delta-P J$ theory by $\Delta-P J$-cosemanticness and connection with its atomic and prime models]. Almaty: Bulletin KazNU, 4(59), 10-17 [in Russian].

14 Itay, Ben-Yaacov. (2003). Positive model theory and compact abstract theories. Journal of Mathematical Logic 3, No. 1, 85-118.

15 Itay, Ben-Yaacov. (2005). Compactness and independence in non first order frameworks. Bulletin of Symbolic logic, No. 1, 28-50.

16 Yeshkeyev, A.R. (2015). On Jonsson sets and some their properties. Bulletin of Symbolic Logic, Vol. 21, $1,99,100$.

17 Yeshkeyev, A.R. (2016). Properties of central type for fragments of Jonsson sets. Bulletin of Symbolic Logic, Vol. 22, 3, 429, 430. 